\title{
CORPORATE FINANCING AND MACROECONOMIC VOLATILITY IN THE EUROPEAN UNION
}

\author{
Andy Mullineux, Victor Murinde and Rudra Sensarma
}

Birmingham Business School, Birmingham B15 2TT, UK

\begin{abstract}
This paper examines the impact of corporate financing patterns in the European Union (EU) on macroeconomic volatility. Using data for a panel of eight EU countries over the years 1989 through 2005, we find that bank financing is positively associated with volatility in GDP, consumption and investment. On the other hand, macroeconomic volatility declines with increased dependence on market based financing from the stock and bond markets.
\end{abstract}

JEL Classifications: E21, E50

Keywords: Corporate financing, EU, fixed-effects regression, macroeconomic volatility

\section{Correspondence to:}

Andy Mullineux

Birmingham Business School

University of Birmingham

Birmingham B15 2TT

UK

Tel: +44-121-414-6704

Email: $\underline{\text { A.W.Mullineux @bham.ac.uk }}$ 


\section{Introduction}

The last two decades have been characterized by a fall in output volatility across industrialized nations, a phenomenon which has been dubbed as 'the great moderation' (Summers, 2005). Several factors have been adduced to explain this phenomenon, ranging from better macroeconomic policies, structural changes in inventory management and simply good luck. While a growing body of research has tried to identify the main driver of the great moderation, most of the studies have been limited to the context of the US. However there is evidence to suggest that Europe has also experienced declining macroeconomic volatility (Summers, 2005; Kent et al., 2005; Barrell, 2004).

Empirical studies suggest that financial integration (see Gavin and Hausmann, 1996) and financial development (Easterly et al., 2001; Denizer et al, 2002) can help to engender macroeconomic stability. However, as the debate over bank versus market based financial systems has shown, the different segments of a financial system can have different implications for the macro-economy (Levine, 2002). As firms depend on a wide range of sources for their financing requirements, it is important to examine whether corporate financing patterns can impact macroeconomic volatility. In this paper we examine whether macroeconomic volatility is dependent on the extent to which firms depend on stock markets, bond markets and banks for their external financing needs. Towards this end, we analyze the impact of corporate financing patterns on macroeconomic volatility in the EU. 
One of the important goals behind the formation of the EU has been the attainment of financial stability and financial integration. A number of studies have suggested that financial convergence is underway in the EU (Bertero, 1994; Corbett and Jenkinson, 1996). More recently, Mullineux et al. (2007) found that corporate financing patterns in EU countries are converging towards increased dependence on stock and bond markets and a reduced share of borrowings from the banking sector. Rajan and Zingales (2003) opine that the efficacy of a particular mode of financing depends on environmental conditions and that the current stages of development of most European countries appear to favour market based financing rather than bank lending. Our results provide empirical support for Rajan and Zingales' argument by assessing the impact of the recent trend in corporate financing in the EU on macroeconomic volatility.

We examine data for a panel of eight EU countries, viz. Finland, France, Germany, Italy, the Netherlands, Spain, Sweden and the UK over the years 1989 through 2005. These countries were selected due to ease of data availability. Employing the methodology of fixed effects regression (Baltagi, 2005), we find that bank financing is positively associated with GDP, consumption and investment volatility. On the other hand, macroeconomic volatility declines with increased dependence on market based financing from the stock and bond markets. In other words, we find that the recent convergence in corporate financing in the EU appears to have enhanced macroeconomic stability.

Our findings are in line with the predictions of the theoretical corporate finance literature. Theoretical work by Brander and Lewis (1986) suggests that higher reliance on debt 
financing encourage firms to take more risks. We can expect this to generate output volatility which in the aggregate would contribute to higher macroeconomic volatility. For the case of the EU, Mullineux et al (2007) have shown that the countries are moving from debt based financing to more market based financing. Therefore this trend could be expected to lead to lower macroeconomic volatility in the EU countries. In what follows, our empirical results are able to confirm these expectations.

The rest of the paper is organized as follows. Section 2 outlines the empirical strategy and data used in the paper. Section 3 presents and discusses the results. Finally, section 4 concludes with a summary of the paper and a discussion of its implications.

\section{Empirical Procedures}

\subsection{The Empirical Model}

The theoretical justification for macroeconomic volatility being dependent on corporate financing patterns can be found in the corporate finance literature. It has been argued in the literature on oligopoly and financial structure that debt financing causes firms to behave more aggressively in the product markets due to the limited liability nature of debt (see the seminal work of Brander and Lewis, 1986 and others). In other words, debt financing encourages risk taking and is expected to create output volatility. Aggregating across firms for the entire economy, we can expect that increased dependence on debt financing would lead to higher macroeconomic volatility. For the case of the EU, this argument leads us to expect that the reduced dependence on debt financing (as indicated by the convergence results of Mullineux et al, 2007) should have led to lower 
macroeconomic volatility. In fact we argue that a move from bank based financing to market based financing (from bond and equity markets) should also offer the benefits of risk diversification leading to lower macroeconomic volatility. Since our objective is to study the impact of corporate financing patterns on macroeconomic volatility, we formulate two separate estimable models to examine this question. First we express macroeconomic volatility as being dependent on the shares of financing from each individual source viz. bank, equity and bond markets as given by equation (1).

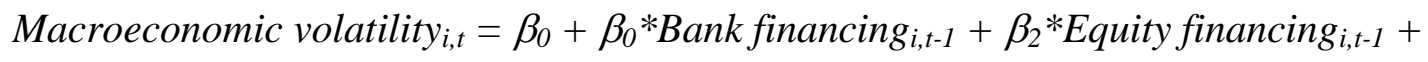
$\beta_{3} *$ Bond financing $_{i, t-1}+\beta_{4} *$ Macroeconomic variables $_{i, t}+e_{i, t}$

Here, each corporate financing variable is a share of the financing from the corresponding market to total financing. The coefficients of each of the three variables would signify the role of each mode of financing on macroeconomic volatility. Macroeconomic variables denote various controls that take care of other factors that may determine macroeconomic volatility.

Next we allow macroeconomic volatility to be dependent on the relative importance of a particular type of financing to all other sources, viz. debt financing relative to equity financing or bank financing relative to market-based financing as shown in equation (2).

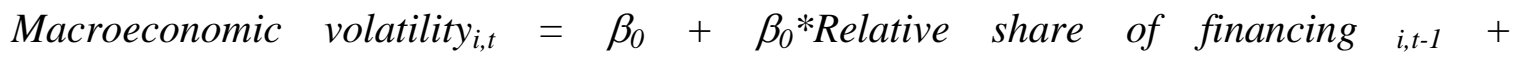
$\beta_{1} *$ Macroeconomic variables ${ }_{i, t}+e_{i, t}$ 
Here, the explanatory variable is either the debt financing to equity financing ratio or is the bank financing to market-based financing ratio. This model serves to investigate the relation between macroeconomic volatility and corporate financing trend, e.g. if the EU countries are moving from debt financing towards more equity financing then the coefficient of the explanatory variable would denote the impact of this trend on macroeconomic volatility. Similarly the coefficient of the bank financing to market-based financing ratio would indicate the impact of the move towards more market based financing on macroeconomic volatility. As before, Macroeconomic variables denote various controls that take care of other factors that may determine macroeconomic volatility.

\subsection{Data and Measurement of Volatility}

We employ data for 8 EU countries (Finland, France, Germany, Italy, Netherlands, Spain, Sweden and the UK) for the period 1989-2005. The data are taken from the IMF's International Financial Statistics database and the World Bank website. We collect data on the following variables: GDP, consumption, investment and indicators of corporate financing from banking, stock and bond markets. GDP, consumption and investment are taken in real per-capita terms. To construct our measures of macroeconomic volatility, we compute standard deviations of quarterly growth rates of GDP, consumption and investment in each year for each country. This gives us three sets of annual series on macroeconomic volatility for each country which we can then relate with the annual data on corporate financing. 


\subsection{Estimation and Testing}

We use fixed-effects panel estimation technique on annual data for the 8 countries to estimate a variety of specifications of the equations (1) and (2). We regress each of the above three measures of macroeconomic volatility on lags of individual indicators of banking, stock and bond market financing to estimate equation (1). Next we regress the three measures of macroeconomic volatility on lags of the share of debt financing and bank financing to other sources of financing to estimate equation (2). For both models, we employ a number of macroeconomic variables such as inflation, exchange rate, degree of openness and foreign direct investment (FDI) as controls that serve to make our regression results robust to alternative specifications (Denizer et al, 2002).

\section{Results}

In Table 1, we first present results from simple two-variable regressions, where each measure of macroeconomic volatility is regressed on (lagged) one financial market indicator. We employ the following variables as indicators of corporate financing from different sources: private credit by deposit money banks to GDP ratio (indicating bank financing), stock market capitalization to GDP ratio (indicating equity financing) and corporate bond market capitalization to GDP ratio (indicating bond financing). In order to measure the relative importance of debt, we proxy leverage by the ratio of debt financing (the sum of bank and bond financing) to equity financing. Finally we proxy the importance of bank financing vis-à-vis other sources of financing by taking the ratio of bank financing to market based financing (the sum of bond and equity financing). 
The regression results reported in Table 1 suggest that banking sector financing significantly impacts output volatility but does not have any significant impact on consumption and investment volatility. The coefficients suggest that greater corporate financing from the banking sector is associated with higher output volatility. On the other hand, stock market capitalization has negative and significant coefficients in the regression for output volatility as well as for consumption and investment volatility. These results suggest that stock market financing leads to lower output, consumption and investment volatility. Finally, the bond market financing appears to negatively impact macroeconomic volatility, but the coefficients are statistically insignificant. In sum, the transition of EU countries from bank based financing to more market based financing appears to have increased macroeconomic stability. We also find that the coefficient of leverage ratio and bank to market financing ratio are positive and significant in the output, consumption and investment volatility regressions. This suggests that a move from debt to equity financing and a move from bank to market based financing lead to lower macroeconomic volatility.

Tables 2 to 4 present results from estimating equation (1), i.e. we regress macroeconomic volatility on a combination of (lagged) financial market indicators with and without the inclusion of macroeconomic control variables. The impact of the quantum of corporate financing from different financial markets on output volatility is summarized in Table 2. The results in Table 2 indicate that borrowing from the banking sector leads to higher output volatility, but stock market financing leads to lower output volatility. The impact 
of bond market financing on output volatility appears to be negative, although the coefficient is statistically significant only in the specification shown by model 3. Among the control variables, only FDI appears to have a significant role. Its coefficient suggests that dependence of capital formation on capital inflows has an adverse impact on output stability.

Table 3 summarizes the results for consumption volatility. The results indicate that dependence on bank financing leads to higher volatility whereas financing from equity and bond markets reduces volatility. Among the control variables, inflation seems to increase consumption volatility which could be because of the business uncertainty associated with an environment of price fluctuations. Table 4 reports the results for investment volatility. The results indicate that bank financing enhances investment volatility whereas equity financing reduces it. However the impact of bond financing on investment volatility is not statistically significant. Among the control variables, while inflation is positively associated with volatility as before, openness appears to be negatively impacting investment volatility indicating the diversification benefits of a country engaged in trade with the rest of the world.

Tables 5 to 7 report regressions of macroeconomic volatility on the relative importance of financial markets in corporate financing. In Table 5, models 1 and 2 report the results from regressing output volatility on leverage. Models 3 and 4 report the results from regressing output volatility on the ratio of bank financing to market based financing. Tables 6 and 7 repeat these regressions for consumption and investment volatility. The 
results are as expected. In other words, increasing reliance on debt financing or bank financing appears to increase output volatility whereas stock market financing or market based financing seems to promote output stability. Similar results hold for consumption and investment volatility. Thus our empirical findings confirm the predictions of the theoretical literature that debt financing enhances risk and a move from bank financing to market based financing offers the benefits of risk diversification. In line with this argument, the EU countries seem to have experienced lower macroeconomic volatility caused by the shift in their corporate financing patterns.

\section{Concluding Remarks}

In a recent study, Mullinuex et al (2007) show that corporate financing patterns in EU countries are converging increasingly towards dependence on stock and bond markets, with a reduced share of borrowings from the banking sector. Rajan and Zingales (2003) suggest that a move from more bank based to more market based financing should be beneficial for EU countries. This paper attempts to examine whether the move from bank based to market based financing has reduced macroeconomic volatility in EU countries. Employing data for a panel of eight EU countries over the years 1989 through 2005, we find that bank financing is positively associated with volatility in GDP, consumption and investment. On the other hand, macroeconomic volatility declines with increased reliance on stock and bond markets. Our results seem to suggest that the recent convergent trends in corporate financing in the EU have contributed to a reduction in macroeconomic volatility. 


\section{References}

Baltagi, B. H., 2005. Econometric Analysis of Panel Data, $3^{\text {rd }}$ edition, John Wiley \& Sons, New York.

Barrell, R. and Davis, E. P., 2005. "Policy Design and Macroeconomic Stability in Europe", National Institute Economic Review, 191(1), 94-105.

Bertero, E. (1994). "The banking system, financial markets and capital structure: some evidence from France", Oxford Review of Economic Policy, 1014, 68-78.

Brander, J. A. and Lewis, T. R. (1986). "Oligopoly and Financial Structure: The Limited Liability Effect", American Economic Review, 76(5), 956-970.

Corbett, J. and Jenkinson, T. (1996). "The financing of industry, 1970-1989: an international comparison", Journal of the Japanese and International Economies, 10(1), 71-96.

Denizer, C.A.., Iyiguni, M.F. and Owen, A., 2002. "Finance and Macroeconomic Volatility", Contributions to Macroeconomics, Berkeley Electronic Press, 2 (1), 130.

Easterly, W., Islam, R. and Stiglitz, J. E., 2001. "Shaken and Stirred: Explaining Growth Volatility." Annual World Bank Conference on Development Economics, Edited by B. Pleskovic and N. Stern (Washington: World Bank).

Gavin, M. and Hausmann, R., 1996. "Sources of Macroeconomic Volatility in Developing Countries." IDB Working Paper. Inter-American Development Bank, Washington, D.C.

Kent, C., Smith, K. and Holloway, J. 2005. "Declining Output Volatility: What Role for Structural Change?", Research Discussion Papers 2005-08, Reserve Bank of Australia.

Levine, R., 2002. "Bank-Based or Market-Based Financial Systems: Which Is Better?," Journal of Financial Intermediation, 11(4), 398-428.

Mullineux, A., Murinde, V. and Sensarma, R., 2007. "Evolving Corporate Financing Patterns in Europe: Is there Convergence?", Working Paper (v.murinde@bham.ac.uk). 
Rajan, R. G. and Zingales, L., 2003. "Banks and Markets: the Changing Character of European Finance", Discussion Papers 3865, Centre for Economic Policy Research, London.

Summers, P. M., 2005. "What caused the Great Moderation?: some cross-country evidence," Economic Review, Federal Reserve Bank of Kansas City, Third quarter, $5-32$. 
Table 1: Two-variable regressions

\begin{tabular}{lllllllllll}
\hline & \multicolumn{3}{c}{ Output volatility } & \multicolumn{3}{c}{ Consumption volatility } & \multicolumn{4}{c}{$\begin{array}{c}\text { Investment } \\
\text { volatility }\end{array}$} \\
\hline Independent variable & Coeff & P-value & R-sq & Coeff & P-value & R-sq & Coeff & $\begin{array}{l}\text { P- } \\
\text { value }\end{array}$ & R-sq \\
Bank financing & & 0.749 & 0.018 & 0.182 & -0.258 & 0.791 & 0.079 & 1.896 & 0.217 & 0.112 \\
Equity financing & -0.487 & 0.008 & 0.006 & -2.202 & 0.000 & 0.023 & -3.581 & 0.000 & 0.003 \\
Bond financing & & -1.125 & 0.242 & 0.093 & -3.909 & 0.201 & 0.023 & -0.404 & 0.929 & 0.052 \\
Leverage ratio $_{\mathrm{t}-1}$ & 0.105 & 0.008 & 0.028 & 0.621 & 0.000 & 0.016 & 1.264 & 0.000 & 0.010 \\
$\begin{array}{l}\text { Bank to Market } \\
\text { financing ratio }\end{array}$ & 0.673 & 0.001 & 0.213 & 1.595 & 0.000 & 0.003 & 5.886 & 0.000 & 0.038 \\
\hline
\end{tabular}

Note: Bank financing = Private credit by deposit money banks/GDP, Equity financing = Stock market capitalization/GDP; Bond financing $=$ Private bond market capitalization/GDP, Leverage ratio $=$ (Bank financing + Bond financing $) /$ Equity financing, Bank to Market financing ratio $=$ Bank financing/(Equity financing + Bond financing) 
Table 2: Output volatility and corporate financing

\begin{tabular}{|c|c|c|c|c|c|c|}
\hline & \multicolumn{2}{|c|}{ Model 1} & \multicolumn{2}{|c|}{ Model 2} & \multicolumn{2}{|c|}{ Model 3} \\
\hline & Coeff & P-value & Coeff & $\mathrm{P}$-value & Coeff & P-value \\
\hline \multicolumn{7}{|l|}{ Corporate financing } \\
\hline Bank financing $\mathrm{t}_{\mathrm{t}-1}$ & 0.997 & 0.002 & 1.119 & 0.001 & 0.939 & 0.002 \\
\hline Equity financing $_{\mathrm{t}-1}$ & -0.438 & 0.009 & -0.412 & 0.016 & -0.687 & 0.000 \\
\hline Bond financing $\mathrm{t}_{\mathrm{-}-1}$ & -1.061 & 0.228 & -0.974 & 0.281 & -1.523 & 0.073 \\
\hline \multicolumn{7}{|c|}{ Macroeconomic controls } \\
\hline Inflation $_{\mathrm{t}}$ & & & 0.066 & 0.216 & 0.054 & 0.277 \\
\hline Exchange rate $_{t}$ & & & 0.000 & 0.843 & 0.000 & 0.743 \\
\hline Openness $_{t}$ & & & -0.002 & 0.319 & -0.002 & 0.401 \\
\hline $\mathrm{FDI} / \mathrm{GDP}_{\mathrm{t}}$ & & & & & 0.048 & 0.000 \\
\hline Constant & 1.993 & 0.000 & 2.063 & 0.000 & 2.359 & 0.000 \\
\hline F-statistic & 5.320 & 0.002 & 3.280 & 0.006 & 5.840 & 0.000 \\
\hline R-square & 0.327 & & 0.089 & & 0.051 & \\
\hline
\end{tabular}

Note: See note to Table 1

Table 3: Consumption volatility and corporate financing

\begin{tabular}{|c|c|c|c|c|c|c|}
\hline & \multicolumn{2}{|c|}{ Model 1} & \multicolumn{2}{|c|}{ Model 2} & \multicolumn{2}{|c|}{ Model 3} \\
\hline Corporate financing & Coeff & P-value & Coeff & P-value & Coeff & P-value \\
\hline Bank financing ${ }_{t-1}$ & 0.322 & 0.763 & 0.975 & 0.332 & 1.092 & 0.283 \\
\hline Equity financing $_{\mathrm{t}-1}$ & -2.227 & 0.000 & -1.809 & 0.001 & -1.631 & 0.005 \\
\hline $\begin{array}{l}\text { Bond financing } \mathrm{t}-1 \\
\text { Macroeconomic controls }\end{array}$ & -3.382 & 0.262 & -2.286 & 0.418 & -1.931 & 0.500 \\
\hline Inflation & & & 0.718 & 0.000 & 0.726 & 0.000 \\
\hline Exchange rate $_{t}$ & & & -0.001 & 0.706 & -0.001 & 0.723 \\
\hline Openness $_{t}$ & & & -0.005 & 0.473 & -0.006 & 0.447 \\
\hline $\mathrm{FDI} / \mathrm{GDP}_{\mathrm{t}}$ & & & & & -0.031 & 0.421 \\
\hline Constant & 7.156 & 0.000 & 5.116 & 0.004 & 4.924 & 0.007 \\
\hline F-statistic & 5.520 & 0.002 & 7.330 & 0.000 & 6.360 & \\
\hline R-square & 0.001 & & 0.043 & & 0.035 & \\
\hline
\end{tabular}

Note: See note to Table 1 
Table 4: Investment volatility and corporate financing

\begin{tabular}{|c|c|c|c|c|c|c|}
\hline & \multicolumn{2}{|c|}{ Model 1} & \multicolumn{2}{|c|}{ Model 2} & \multicolumn{2}{|c|}{ Model 3} \\
\hline & Coeff & P-value & Coeff & P-value & Coeff & P-value \\
\hline \multicolumn{7}{|l|}{ Corporate financing } \\
\hline Bank financing $\mathrm{t}_{\mathrm{t}-1}$ & 2.445 & 0.126 & 3.549 & 0.024 & 3.808 & 0.016 \\
\hline Equity financing ${ }_{t-1}$ & -3.693 & 0.000 & -3.356 & 0.000 & -2.959 & 0.001 \\
\hline Bond financing $_{\mathrm{t}-1}$ & -1.389 & 0.756 & -0.265 & 0.952 & 0.525 & 0.905 \\
\hline \multicolumn{7}{|c|}{ Macroeconomic controls } \\
\hline Inflation $_{\mathrm{t}}$ & & & 0.709 & 0.007 & 0.727 & 0.006 \\
\hline Exchange rate $_{t}$ & & & -0.001 & 0.609 & -0.001 & 0.631 \\
\hline Openness $_{t}$ & & & -0.019 & 0.106 & -0.020 & 0.093 \\
\hline $\mathrm{FDI} / \mathrm{GDP}_{\mathrm{t}}$ & & & & & -0.068 & 0.247 \\
\hline Constant & 7.927 & 0.000 & 7.783 & 0.005 & 7.357 & 0.008 \\
\hline F-statistic & 6.980 & 0.000 & 6.340 & 0.000 & 5.650 & 0.000 \\
\hline R-square & 0.021 & & 0.009 & & 0.006 & \\
\hline
\end{tabular}

Note: See note to Table 1

Table 5: Output volatility and relative importance of sources of financing

\begin{tabular}{|c|c|c|c|c|c|c|c|c|}
\hline & \multicolumn{2}{|c|}{ Model 1} & \multicolumn{2}{|c|}{ Model 2} & \multicolumn{2}{|c|}{ Model 3} & \multicolumn{2}{|c|}{ Model 4} \\
\hline Share of corporate financing & Coeff & P-value & Coeff & P-value & Coeff & P-value & Coeff & P-value \\
\hline $\begin{array}{l}\text { Leverage ratio } t-1 \\
\text { Bank to Market financing } \\
\text { ratio } t-1\end{array}$ & 0.094 & 0.029 & 0.128 & 0.002 & 0.650 & 0.003 & 0.847 & 0.000 \\
\hline Macroeconomic controls & & & & & & & & \\
\hline Inflation $_{\mathrm{t}}$ & 0.042 & 0.469 & 0.034 & 0.532 & 0.028 & 0.623 & 0.018 & 0.728 \\
\hline Exchange rate $_{t}$ & 0.000 & 0.954 & 0.000 & 0.848 & 0.000 & 0.969 & 0.000 & 0.790 \\
\hline Openness $_{t}$ & 0.000 & 0.968 & 0.001 & 0.724 & -0.001 & 0.598 & -0.001 & 0.674 \\
\hline $\mathrm{FDI} / \mathrm{GDP}_{\mathrm{t}}$ & & & 0.042 & 0.000 & & & 0.045 & 0.000 \\
\hline Constant & 1.814 & 0.000 & 1.482 & 0.001 & 1.680 & 0.000 & 1.302 & 0.003 \\
\hline F-statistic & 1.910 & 0.114 & 4.620 & 0.001 & 3.010 & 0.022 & 6.270 & 0.000 \\
\hline R-square & 0.050 & & 0.001 & & 0.090 & & 0.025 & \\
\hline
\end{tabular}

Note: See note to Table 1 
Table 6: Consumption volatility and relative importance of sources of financing

\begin{tabular}{|c|c|c|c|c|c|c|c|c|}
\hline & \multicolumn{2}{|c|}{ Model 1} & \multicolumn{2}{|c|}{ Model 2} & \multicolumn{2}{|c|}{ Model 3} & \multicolumn{2}{|c|}{ Model 4} \\
\hline Share of corporate financing & Coeff & P-value & Coeff & P-value & Coeff & P-value & Coeff & P-value \\
\hline $\begin{array}{l}\text { Leverage ratio } t-1 \\
\text { Bank to Market financing } \\
\text { ratio } t-1\end{array}$ & 0.438 & 0.001 & 0.403 & 0.002 & 2.381 & 0.000 & 2.202 & 0.001 \\
\hline Macroeconomic controls & & & & & & & & \\
\hline Inflation $_{t}$ & 0.638 & 0.000 & 0.647 & 0.000 & 0.626 & 0.000 & 0.635 & 0.000 \\
\hline Exchange rate $_{t}$ & 0.000 & 0.805 & 0.000 & 0.871 & -0.001 & 0.720 & 0.000 & 0.786 \\
\hline Openness $_{t}$ & 0.000 & 0.975 & -0.001 & 0.893 & -0.005 & 0.462 & -0.006 & 0.436 \\
\hline $\mathrm{FDI} / \mathrm{GDP}_{\mathrm{t}}$ & & & -0.044 & 0.211 & & & -0.041 & 0.244 \\
\hline Constant & 2.053 & 0.138 & 2.400 & 0.089 & 1.777 & 0.200 & 2.121 & 0.135 \\
\hline F-statistic & 11.050 & 0.000 & 9.210 & 0.000 & 11.550 & 0.000 & 9.550 & 0.000 \\
\hline R-square & 0.073 & & 0.057 & & 0.027 & & 0.022 & \\
\hline
\end{tabular}

Note: See note to Table 1

Table 7: Investment volatility and relative importance of sources of financing

\begin{tabular}{|c|c|c|c|c|c|c|c|c|}
\hline & \multicolumn{2}{|c|}{ Model 1} & \multicolumn{2}{|c|}{ Model 2} & \multicolumn{2}{|c|}{ Model 3} & \multicolumn{2}{|c|}{ Model 4} \\
\hline Share of corporate financing & Coeff & P-value & Coeff & P-value & Coeff & P-value & Coeff & P-value \\
\hline $\begin{array}{l}\text { Leverage ratio } \mathrm{t}-1 \\
\text { Bank to Market financing }\end{array}$ & 1.151 & 0.000 & 1.111 & 0.000 & & & & \\
\hline $\begin{array}{l}\text { ratio } \mathrm{t}-1 \\
\text { Macroeconomic controls }\end{array}$ & & & & & 5.486 & 0.000 & 5.262 & 0.000 \\
\hline Inflation $_{\mathrm{t}}$ & 0.399 & 0.108 & 0.408 & 0.101 & 0.429 & 0.094 & 0.440 & 0.086 \\
\hline Exchange rate $_{t}$ & 0.000 & 0.840 & 0.001 & 0.790 & 0.000 & 0.954 & 0.000 & 0.988 \\
\hline Openness $_{t}$ & -0.007 & 0.534 & -0.007 & 0.484 & -0.019 & 0.091 & -0.019 & 0.085 \\
\hline $\mathrm{FDI} / \mathrm{GDP}_{\mathrm{t}}$ & & & -0.049 & 0.331 & & & -0.050 & 0.332 \\
\hline Constant & 3.669 & 0.067 & 4.059 & 0.047 & 3.363 & 0.105 & 3.790 & 0.075 \\
\hline F-statistic & 14.900 & 0.000 & 12.110 & 0.000 & 12.740 & 0.000 & 10.380 & 0.000 \\
\hline R-square & 0.016 & & 0.012 & & 0.001 & & 0.001 & \\
\hline
\end{tabular}

Note: See note to Table 1 